
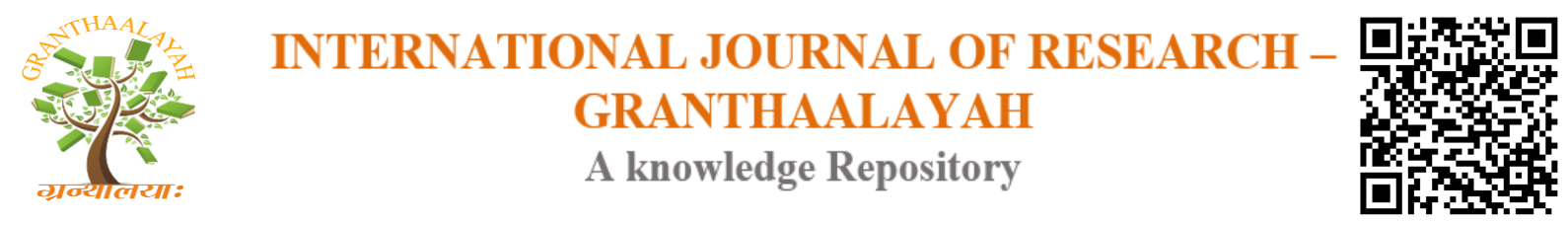

Social

\title{
THE USE OF PHONICS INSTRUCTION TO ENHANCE STUDENTS' READING ABILITY: A CASE STUDY OF GRADE 3 STUDENTS AT NAM YUEN SCHOOL, NAM YUEN DISTRICT, UBON RATCHATHANI PROVINCE
}

\author{
Ms. Jidanan Thaen-nga ${ }^{* 1}$, Asst. Prof. Dr. Wutti Leenam ${ }^{2}$ \\ ${ }^{* 1,2}$ Department of English, Ubon Ratchathani Rajabhat University, THAILAND
}

DOI: https://doi.org/10.29121/granthaalayah.v4.i10.2016.2493

\section{ABSTRACT}

The purpose of this research was to study English reading ability after being taught through the phonics instruction. The target group was 30 Grade 3 students enrolled in English course in the second semester of academic year 2015 at Nam Yuen School, Nam Yuen District, Ubon Ratchathani Province. The experimental instrument was 5 lesson plans using phonics instruction. The instruments were the tests used before starting and after finishing each lesson. The data obtained were analyzed using mean, percentage and standard deviation.

The findings revealed a statistically significant main effect $(P<.001)$ indicating that there was a significant difference between the mean scores of the pretest and the posttest which means that the students increased their oral reading ability after being taught through phonics.

Keywords:

the use of phonics instruction; grade 3 students; phonics; oral reading ability.

Cite This Article: Ms. Jidanan Thaen-nga, and Asst. Prof. Dr. Wutti Leenam, "THE USE OF PHONICS INSTRUCTION TO ENHANCE STUDENTS' READING ABILITY: A CASE STUDY OF GRADE 3 STUDENTS AT NAM YUEN SCHOOL, NAM YUEN DISTRICT, UBON RATCHATHANI PROVINCE" International Journal of Research - Granthaalayah, Vol. 4, No. 10 (2016): 65-71.

\section{INTRODUCTION}

Reading is one of the four necessary important language skills for those learning English as a second language, for academic success and for professional development because reading is the basis for all other areas of learning (Dentisak Dorkchandra, 2010:1). It is necessary to ensure that children of the primary grade attain proficiency in reading. This implies that teachers in the primary grades will have to vary traditional methods of teaching, and improve their knowledge base by engaging in training, including information communication technology (ICT) training (Carter, 2000:3). However, Thai learners have encountered difficulties and problems in learning 
reading skill for a long time. Nongnat Chawwang (2002: 2) states that most of ESL/EFL students have problems in reading English texts because they have limited knowledge of vocabularies and sentence structures. Dentisak Dorkchandra (2010:1) has gathered several causes that affect students' reading abilities which include a lack of reading resources, cultures, strategy knowledge, and he has also found that teachers use unsuccessful teaching methods. To find out the truth of these above statements, the researcher has interviewed and observed three teachers and twenty Grand 3 students from Nam Yuen School in Nam Yuen district and Anubal Buntharik School in Buntharik district located in the rural area in Thailand

The researcher has learned that some teachers still use traditional ways of teaching method such as teaching them to remember words and, do exercises in practice books. Sometimes, students practice their listening skill by watching English cartoons or movies at school. However, when they were required to read and write some simple words, for example a pen, hit, and tall, not every one of them could do that. They could not sound out the words correctly. They do not know how to convert letters and combine them into sounds, and how to blend the sounds together to form recognizable words. They could tell the meaning of the word by hearing the sound but they could not read any written words.

Fambro (2011:3) states that one reason is that they do not have basic phonics skills to help them to read. Children should be taught phonics, in a whole group setting using story text, basal readers and during a scheduled, direct phonics instruction time.

According to Fambro (2011:3) and Hoffman (2014), all reading programs should contain a phonics component and students who learn phonics early do better in reading than those who do not. Liu (2005:1) also states that phonics is the system of teaching reading that builds on the alphabetic principle, a system of which a central component is the teaching correspondences between letters or groups of letters and their pronunciation. To be successful at phonics, one must possess the skills to hear sounds within words (known as phonemic awareness) and automatically to recognize letters of alphabet. Armbrustet, Lehrer, \& Osborn also supported that Phonics teaches student to understand and learn the relationship between the letter (graphemes) of written language and the individual sounds (phonemes) of spoken language. It also teaches children how to use these relationships to read and write words accurately (as cited in Martinez, 2011:27). The department for education in the UK (2013) has concluded the importance of phonics instruction in ' Evidence check' memorandum Phonics policy by committing that teaching phonics in primary schools is acquired because it offers the best and most direct route to becoming skilled readers and enables the children to read and spell better than those taught by alternative approaches. Furthermore, UK and international research shows that systematic phonics teaching in a language -rich curriculum, is the most effective way of teaching reading to children of all abilities and educational backgrounds.

Based on the notice presented above, the researcher, therefore, wish to investigate whether students reading ability will improve significantly if they are taught with the phonics instruction. 


\section{PURPOSE OF THE STUDY}

The purpose of this study is to investigate the effect of phonics instruction on the development of English reading ability of Grade 3 students at Nam Yuen school by using phonics instruction.

\section{RESEARCH QUESTION}

The purpose of this study is to determine whether phonics instruction helps students enhance English reading ability and to what extent.

\section{SCOPE OF THE STUDY}

The study covered the population and the sample of 65 Grade 3 students of Nam Yuen School who were taught through phonics instruction using various phonics activities. The reading assessment based on pretest and posttest, and teacher's observation. Five lesson plans were well prepared for students to learn.

\section{EXPECTED OUTCOME}

The expected outcome of this study will determine the effectiveness of the English teacher using synthetic phonics in the classroom at Nam Yuen School. Phonics instruction that is taught in the classroom will be helpful for students who have poor reading and lack of vocabulary knowledge. The result is expected to be found after teacher teaches students by using phonics instruction in the classroom and then the learners will be evaluated.

\section{MATERIALS AND METHODS}

\section{POPULATION AND SAMPLE}

In this study, the population was 65 Grade 3 students in Nam Yuen School, Nam Yuen district in the second semester of academic year 2015. The sampling group was 30 students in Grade 3 of the same school, selected by simple random sampling.

\section{RESEARCH DESIGN AND INSTRUMENTS}

The research design was based on a one group pretest posttest design. The students were tested on words reading before and after teaching by phonics instruction.

\begin{tabular}{|l|l|l|l|}
\hline Sample & $\mathrm{O}_{1}$ & $\mathrm{X}$ & $\mathrm{O}_{2}$ \\
\hline
\end{tabular}

$$
\begin{array}{lll}
\text { Sample } & = & \text { Grade } 3 \text { students of Nam Yuen school, Nam Yuen district } \\
\mathrm{O}_{1} & = & \text { Pretest } \\
\mathrm{X} & = & \text { Phonics instruction } \\
\mathrm{O}_{2} & = & \text { Posttest }
\end{array}
$$

In this study, the instruments for data collection were designed as follows: 
1) Phonics teaching plans The phonics teaching plans were used 3 periods in a week totally 18 periods divided into 2 parts: part one consisting of 3 periods for introducing the sounds of Aa to Zz; part two consisting of 15 periods for teaching short vowel sounds, a, e, i, o, u using the phonics instruction. The target words were selected according to the phonics sounds that are taught by using synthetic phonics adapted from Jolly Phonics Program and were compiled from "Basic English 3" by Samerjit Sajjapiyanijkul, and Express Student Workbook 3 , various activities were used in teaching reading step-by step process depending on the lesson plan.

2) Pretest and posttest The pretest and posttest papers were used for the achievement test on word reading. The test was piloted with students at Anubal Buntharik School whose English ability was relatively the same as the subject in this study. After that it was tested by the experts to improve the number of target words before being administered to the subjects. The test consisted of 1 part, word reading.

\section{THE CRITERIA OF READING ASSESSMENT}

The assessment criteria are employed to interpret the meaning of the items (MOE, 2008:34)

\begin{tabular}{|c|c|c|}
\hline Scores & Effectiveness & Quality \\
\hline $80-100$ & 4 & Excellent \\
\hline $70-79$ & 3 & Good \\
\hline $60-69$ & 2 & Fair \\
\hline $50-59$ & 1 & Poor \\
\hline $0-49$ & 0 & very poor \\
\hline
\end{tabular}

The data were collected during the second semester of the academic year 2015 at Nam Yuen School, Ubon Ratchathani province. The intervention period is from December 2014 to March 2015. The researcher will spend 18 hours teaching the course. There are 2 research instruments as a source of data: pretest and posttest, phonics teaching plans. The following description of the lesson explains when and how data will be collected.

1) In the first meeting with the students, the teacher introduces the letter sounds by using the capital and lowercase consonant letter cards. The teacher also explains the role of phonics in reading to the students. After that, students took the pretest.

2) The researcher used the capital and lowercase consonant letter cards to introduce letter sounds in each lesson, picture cards that could be paired with initial consonant letter cards for example Bat (B or b), were used to lead the students into each lesson. After that the students learned how to blend the sounds together to form recognizable word. The teacher provided the exercises and games for the students to practice with.

3) In each lesson, the researcher observed the behavior of students while using phonics instruction and writes a report. 
4) When all lessons were completed, the students took the posttest, which is virtually the same as the pretest including the word reading posttest.

\section{DATA COLLECTION}

The data from the pretest and the posttest (before and after the session) were analyzed by using the Statistical Package for Social Sciences (SPSS) to find mean (x), standard deviation (S.D.), and dependent t-test. The results of the pretest and the posttest were used to determine whether phonics instruction was a significant way to improve reading ability.

\section{RESULTS AND DISCUSSIONS}

This research is to examine the influence that phonics provides in English reading ability of Grade 3 of Nam Yuen School. The results of data analysis were presented in the following aspects:

The comparison of reading ability from the pretest and posttest

Table 1: The comparison of reading ability from pretest and posttest

\begin{tabular}{|l|l|l|l|l|l|l|}
\hline Reading Achievement & $\mathbf{N}$ & $\overline{\mathbf{x}}$ & S.D. & $\mathbf{D}$ & $\mathbf{t}$ & $\begin{array}{l}\text { Sig } \\
\mathbf{1} \text { tailed }\end{array}$ \\
\hline Pretest & 30 & 8.00 & 7.071 & & $39.679^{* * *}$ & 0.000 \\
\hline Posttest & 30 & 39.80 & 7.058 & 31.80 & 0.000 \\
\hline
\end{tabular}

** Statistically significance at .01

According to Table 1, the t-test revealed a statistically significant main effect $($ sig $<.000$ ) indicating that there was a significant difference between the mean scores of the two tests. The support of the research instruments that was the pretest and posttest demonstrated the learners' improvement. It was evidently visible that using phonics had considerable influence in improving the learners' reading ability.

The results obtained indicate that using phonics can help the learners learn to read and form words effectively. Furthermore students' word recognition significantly improved. It seems that teaching reading through phonics can enhance students' word reading for many reasons. Firstly, synthetic phonics played an important role to guide students to learn how to read. After teaching phonics, students were able to pronounce sounds example the sound /v/, then /a/ and the then /t/, blended together to say /vat/, which are represented by individual letters and pronounced together as a word. In addition, the students who are skilled in phonics can sound out the words they have not seen before, without first having to memorize them. It means that the students have learnt a technique that they can use for themselves.

Secondly, the teacher selected various phonics activities for the students which included dictation games, spelling games, word search, flash card and colored pictures books. These made the students remember and retain the knowledge of words in long term memory. Most importantly, these also played important roles in capturing students' interest and motivation in learning. In conclusion the students practiced word recognition and word reading with 
enjoyment. Moreover, using phonics in teaching, students should be given more continued and regular practices in order to make it effective.

Thirdly, the classroom environment played vital role in learning. The teacher provided opportunities for them to practice their phonemic awareness, namely, word cards on the classroom wall, short stories for students to practice oral reading. Reading out-loud while getting guidance and feedback from the teacher, promoted reading fluency. Children gain fluency by practicing reading until the process becomes automatic; guided oral repeated reading is one approach in helping children become fluent readers.

Lastly, the teacher should provide opportunities for children to work in pairs to support each other learning. Students with more ability in learning helped those whose learning ability was lower as they learnt better with the help from the teacher and their classmates.

The finding showed that most students showed significant improvement. However some students showed low improvement. With regard to reasons as to why some students show high and low improvement. One possible reason could be the alphabet knowledge and phonemic awareness skill. Although the researcher had introduced the alphabet and letter sound to them for three periods, students with low English proficiency still required many opportunities with various phonological awareness tasks to become successful. Furthermore, the finding showed that students with strong alphabet knowledge and letter sound learned phonics faster than those with poor skills. Therefore, the teachers should monitor the students informally in order to provide the phonological awareness intervention activity for them at the end of each lesson.

\section{CONCLUSIONS \& RECOMMENDATIONS}

The study clearly confirmed that phonics is an effective tool for improving students' reading ability. Those students were interested in this kind of teaching and enjoying doing it. They had many activities to work on the lessons and share their ideas not only pairs but also groups. The students' reading skill improved gradually.

To sum up, these Grade 3 students clearly enhanced their oral reading ability through the implementation of phonics instruction. The students had positive perceptions about phonics as well; they were satisfied with this kind of teaching. Thus, it was worthwhile teaching English through phonics activities.

\section{RECOMMENDATIONS}

1) In this study, the sampling group was Grade 3 students. The phonics lesson should be used with other levels.

2) Students should practice oral reading using phonics technique as often as possible to boost their learning competence.

3) The reading of pictures as labeling or various short stories with colored picture should be provided for the earliest oral reading in order to boost the students' enjoyment and reading motivation.

4) Some students may need many opportunities with various phonological awareness tasks to become successful. Do not expect mastery of all skills. In addition, the teacher should 
monitor the students informally in order to provide the phonological awareness intervention activity for them at the end of each lesson.

5) Words which do not follow phonics rules should be taught using other methods such as sight word activities.

\section{ACKNOWLEDGEMENTS}

The author wish to deeply thank all teachers and friends from Nam Yeun School for their support, Dr. Nutprapha Kongphet Dennis, for her guidance and useful advice.

\section{REFERENCES}

[1] Dorchandra, D. Enhancing English Reading Comprehension Through a Text Structure Reading Strategy Call Program. Doctoral's Thesis. Suranaree University of Technology, 2010.

[2] Carter, V. E. Teaching Reading in Primary School (online) 2000 (cited 24 February 2014).

[3] Fambro, L. Phonics Instruction: An Important Part of The Reading Curriculum. Master's Thesis. LaGrange, Georgia, 2011

[4] Hoffman, B. 5 Phonics Based Approaches to Reading And Writing (online) 2014 (cited 01 October 2015). Available from http://mylearningspringboard.com/5-phonics-basedapproaches-to-reading-and-writing/

[5] Liu, C.K. Phonics: Theory and Practice (online) 2005 (cited 25 October 2015). Available from http://web.ntpu.edu.tw/ language/workshop/phonics.pdf

[6] Martinez, A. M. Explicit and Differentiated Phonics Instructionas a Tool to Improve Literacy Skills for Children Learning English as a Foreign Language (online) 2011 (cited 24 December 2014). Available from http://files.eric.ed.gov/fulltext/EJ1062615.pdf 